\title{
Airway Injury From Initiating Ventilation in Preterm Sheep
}

\author{
NOAH H. HILLMAN, SUHAS G. KALLAPUR, J. JANE PILLOW, TIMOTHY J. M. MOSS, GRAEME R. POLGLASE, \\ ILIAS NITSOS, AND ALAN H. JOBE
}

\author{
Division of Pulmonary Biology [N.H.H., S.G.K., A.H.J.], University of Cincinnati, Cincinnati, Ohio 45229; School of Women's and \\ Infants' Health [J.J.P., T.J.M.M., G.R.P., I.N.], The University of Western Australia, Perth, WA Australia 6009
}

\begin{abstract}
Premature infants exposed to ventilation are at risk of developing bronchopulmonary dysplasia and persistent lung disease in childhood. We report where injury occurred within the lung after brief ventilation at birth. Preterm sheep (129 d gestation) were ventilated with an escalating tidal volume to $15 \mathrm{~mL} / \mathrm{kg}$ by $15 \mathrm{~min}$ to injure the lungs, with the placental circulation intact (fetal) or after delivery (newborn). Fetal lambs were returned to the uterus for $2 \mathrm{~h} 45 \mathrm{~min}$, whereas newborn lambs were maintained with gentle ventilatory support for the same period. The control group was not ventilated. Bronchoalveolar lavage fluid (BALF) and lung tissue were analyzed. In both fetal and newborn lambs, ventilation caused bronchial epithelial disruption in mediumsized airways. Early growth response protein 1 (Egr-1), monocyte chemotactic protein 1 (MCP-1), IL-6, and IL-1 $\beta$ mRNA increased in the lung tissue from fetal and newborn lambs. Egr-1, MCP-1, and IL-6 mRNA were induced in mesenchymal cells surrounding small airways, whereas IL- $1 \beta$ mRNA localized to the epithelium of medium/small airways. Ventilation caused loss of heat shock protein 70 (HSP70) mRNA from the bronchial epithelium, but induced mRNA in the smooth muscle surrounding large airways. HSP70 protein decreased in the lung tissue and increased in BALF with ventilation. Initiation of ventilation induced a stress response and inflammatory cytokines in small and medium-sized airways. (Pediatr Res 67: 60-65, 2010)
\end{abstract}

$\mathrm{T}$ he majority of extremely low-birth weight (ELBW) infants $(<1000 \mathrm{~g})$ are intubated and receive ventilatory support after delivery (1), but little is known about the effects of mechanical ventilation on the preterm lung. Ventilation from birth has been associated with an increased incidence of bronchopulmonary dysplasia (BPD) (2), and clinical strategies to transition ELBW infants using continuous positive airway pressure $(\mathrm{CPAP})$ in the delivery room may modestly decrease the incidence of BPD $(3,4)$. Although alveolar simplification is the hallmark of BPD in the postsurfactant treatment era, small airway injury continues to be prominent in older children with a history of BPD (5-8). School-age children diagnosed with moderate to severe BPD have decreased forced expiratory volume in $1 \mathrm{sec}\left(\mathrm{FEV}_{1}\right)$, increased respiratory symptoms, and decreased peak flow measurements at $6 \mathrm{y}$ of

Received June 8, 2009; accepted September 6, 2009.

Correspondence: Noah H. Hillman, M.D., Division of Pulmonary Biology, Cincinnati Children's Hospital Medical Center, University of Cincinnati, 3333 Burnet Avenue, Cincinnati, Ohio 45229; e-mail: Noah.Hillman@cchmc.org

Supported by grant HD-12714 from the National Institute of Child Health and Development, a NIH training grant HD07541 (N.H.H.), a Sylvia Viertiel Senior research Fellow (J.J.P.), a NHMRC RD Wright Career Development Award (T.J.M.M.), a NHFA/NHMRC Fellowship (G.R.P.), and the Women's and Infants' Research Foundation and Fisher \& Paykel Healthcare, Auckland, New Zealand.

T.J.M. Moss is currently at Monash University, Melbourne, Australia. life (5). Children born extremely premature also have decreased exercise performance (9).

The transition from a fetus to a newborn requires the initiation of breathing, clearance of fluid from airways, and ventilation of the distal airspaces. Very preterm infants may be more vulnerable to airway injury, because they are born with the lung at the saccular stage of development, before the formation of alveoli (6). In contrast to the adult lung, airways in the preterm lung stretch with normal ventilation and disruptions of airway epithelium are prominent in the lungs of infants who have died of RDS $(10,11)$. The decreased surfactant pools found in premature infants also contribute to nonuniform expansion of the lung by creating areas of focal overdistension and atelectasis (12). We showed previously that regardless of the tidal volume or positive end expiratory pressure (PEEP) used, initiation of ventilation in fluid-filled, surfactant deficient preterm lambs is injurious (13). The preterm lung is likely at risk for small and large airway injury from initiation of ventilation during resuscitation.

We reported previously that fetal ventilation followed by return of the fetus to the uterus for $3 \mathrm{~h}$ can be used to evaluate the initial lung injury response (14). Ventilation of fetal lambs with an escalating tidal volume $\left(\mathrm{V}_{\mathrm{T}}\right)$ to $15 \mathrm{~mL} / \mathrm{kg}$ by $15 \mathrm{~min}$ caused lung injury and inflammation, and indicators of systemic inflammation increased within $3 \mathrm{~h}$ (14). Ventilation increased the proinflammatory cytokine mRNA for monocyte chemotactic protein 1 (MCP-1), IL-6 (IL-6), and IL-1 $\beta$ (IL-1 $\beta$ ) mRNA in the lungs (14). The nuclear transcription factor early growth response protein 1 (Egr-1) promotes expression of proinflammatory cytokines and is inducible by hypoxia and stretch injury within $30 \mathrm{~min}(15,16)$. Heat shock protein 70 (HSP70) is a chaperone protein present in the lung epithelium that is responsive to cellular stresses and may influence inflammatory processes (17). Because fetal sheep, unlike adults, do not have alveolar macrophages to initiate the inflammatory response (18), the epithelium or other tissue components may initiate inflammation. We tested the hypothesis that high tidal volume stretch injury would damage the airways of the preterm and increase the expression of the early response genes Egr-1 and HSP70, and the subsequent expression of early response cytokines.

\footnotetext{
Abbreviations: BAL, bronchoalveolar lavage; BPD, bronchopulmonary dysplasia; Egr-1, early growth response protein 1; HSP70, heat shock protein 70; MCP-1, monocyte chemotactic protein 1
} 


\section{METHODS}

The animal studies were performed in Perth, Western Australia; Cincinnati Children's Hospital and the Western Australia Department of Agriculture approved the animal use procedures. Some indices of global lung injury were previously reported for these animals (14).

Animals were assigned to three groups ( $n=6-8 /$ group $): 1)$ fetal ventilation with placental support (fetal), 2) newborn resuscitation and ventilation (newborn), or 3) controls. After maternal hysterotomy, fetal lambs had their head and chest exteriorized. The fetus was intubated, and lung fluid was removed with modest suction on endotracheal tube $(10-15 \mathrm{~mL}$ per animal). Placental circulation remained intact throughout the procedure. Newborn lambs were surgically delivered, intubated, and lung fluid was removed before 15-min intervention.

Initial 15-min intervention. The fetal and newborn lambs were ventilated (rate 30 breaths/min, inspiratory time $1 \mathrm{~s}, \mathrm{FiO}_{2}$ 0.4) with a Bourns BP200 time-cycled, pressure-limited infant ventilator using $12 \mathrm{~L} / \mathrm{min}$ flow with heated and humidified air and no PEEP. Tidal volumes were increased throughout the ventilation period to achieve $5 \mathrm{~mL} / \mathrm{kg}$ by $5 \mathrm{~min}, 10 \mathrm{~mL} / \mathrm{kg}$ by $10 \mathrm{~min}$, and $15 \mathrm{~mL} / \mathrm{kg}$ by $15 \mathrm{~min}$ of ventilation (14). An inline flow sensor and monitor (Florian Infant Graphics Monitor, Acutronic Medical Systems, Switzerland) continuously measured $\mathrm{V}_{\mathrm{T}}$. Each lamb was treated with $100 \mathrm{mg} / \mathrm{kg}$ bovine surfactant at $15 \mathrm{~min}$ of age (Survanta, Ross Laboratories, OH).

Following 2 h 45-min procedure. Fetal lambs were returned to the uterus, and the ewes were allowed to recover. Each fetal lamb was delivered for plasma and tissue collection $2 \mathrm{~h}$ and $45 \mathrm{~min}$ after the 15 -min fetal ventilation period. After the initial 15 -min ventilation period with escalating tidal volumes, newborn lambs were ventilated ( 40 breaths/min, PEEP $5 \mathrm{~cm} \mathrm{H} \mathrm{H}_{2} 0$, inspiratory time $0.7 \mathrm{~s}, \mathrm{FiO}_{2} 2.40$ ) with a heated and humidified oxygen and air mixture for $2 \mathrm{~h} 45 \mathrm{~min}$. The subsequent ventilation targeted tidal volumes were $7 \mathrm{~mL} / \mathrm{kg}$, similar to those achieved by preterm lambs spontaneously breathing on CPAP (19). Peak inspiratory pressures were adjusted to maintain a tidal volume of $7 \mathrm{~mL} / \mathrm{kg}$ with a targeted $\mathrm{PaCO}_{2}$ of $50 \mathrm{~mm} \mathrm{Hg}$. Samples were collected $2 \mathrm{~h} 45 \mathrm{~min}$ after the end of the initial resuscitation period.

Controls. Nonmanipulated twins of lambs of fetal group had tissue collected after delivery of the twin.

Lung processing and BALF analysis. The lungs were weighed, and the left lung was lavaged with saline three times for bronchoalveolar lavage (BAL) (20). BAL was used for measurement of HSP70. Tissues from the right lung were snap frozen for RNA analysis. The right upper lobe of the lung was inflation fixed with $10 \%$ formalin (21). Injury was scored on blinded hematoxylin-eosin-stained tissue. Ten random high power fields were scored on a 0 to 2 scale for septation thickness $(0=$ thin distal airway walls, $1=$ mild thickening of airway walls with thin alveolar regions, and $2=$ thickening of all airspaces), hemorrhage $(0=$ no hemorrhage, $1=$ hemorrhage into parenchyma, small airway hemorrhages, and $2=$ large airway hemorrhage), inflammation $(0=$ no inflammatory cells, $1=1-5$ cells $/$ hpf, and $2=>5$ inflammatory cells/hpf $)$, and epithelial sloughing $(0=$ no sloughing, $1=$ epithelial wall disruption, and $2=$ denudged epithelium in airspace) (total 8 points). Airways with smooth muscle, glands, and cartilage were identified as large airways; airways with only smooth muscle were considered mediumsized airways; and distal bronchioles without smooth muscle often with branching airspaces were identified as small airways.

Immunohistochemistry. Immunostaining protocols were used as reported (20). Paraffin sections $(5 \mu \mathrm{m})$ of formalin-fixed tissue were pretreated with $3 \%$ hydrogen peroxide to destroy endogenous peroxidases. The sections were incubated with the primary antibody [HSP70 (Biogenex, CA), Egr-1 (Santa Cruz, CA), inducible nitric oxide synthase (iNOS; Transduction, USA), VEGFR2 (Cell Signaling, USA), and IL-1 $\beta$ (internally produced)] with a blocking agent, followed by biotin labeled secondary antibody. Immunostaining was visualized by Vectastain $\mathrm{ABC}$ peroxidase Elite kit to detect the antigen:antibody complexes (Vector Laboratories Inc). The antigen detection was enhanced with nickel-DAB, followed by Tris-cobalt and the nuclei counterstained with nuclear fast red.

Western blots. The lung tissue was homogenized in $50 \mathrm{mM}$ Tris- $\mathrm{HCl}$ buffer, $\mathrm{pH} 7.5$, and $0.1 \mathrm{mM}$ EDTA. Homogenates were centrifuged and supernatants collected. Forty micrograms of protein was denatured, electrophoresed on a 10 to $20 \%$ Tris-glycine gel (Invitrogen, CA), and transferred to a nitrocellulose membrane. The membrane was incubated overnight at $4^{\circ} \mathrm{C}$ with HSP70 antibody diluted 1:1000 in TBS-tween and 5\% milk. The membrane was incubated for $1 \mathrm{~h}$ in room temperature with secondary antibody conjugated to horseradish peroxidase diluted at 1:5000 in 5\% milk. Detection by chemiluminescence was performed using ECL reagents (GE Healthcare, NJ). Beta-actin (C4) (mouse MAb against chicken gizzard actin) as a primary antibody diluted at 1:2000 and a secondary antibody, goat anti-mouse IgG conjugated to horseradish peroxidase (1:5000 dilution) (Santa Cruz Biotechnology) was used to re-probe the blots as loading controls (20).
ELISA for HSP70. A HSP70 ELISA for human HSP70 was cross-reactive with sheep (R\&D Systems, USA) and was used to measure HSP70 in bronchoalveolar lavage fluid (BALF), lung homogenate, and plasma.

RNase protection assays. Total RNA was isolated using a modified Chomzynski method (22), and $10 \mu \mathrm{g}$ of total lung RNA was used for RNase protection assays with sheep-specific riboprobes for IL-1 $\beta$, IL-6, MCP-1, HSP70, Egr-1, VEGF, and L32 (23). Solution hybridization was performed with a molar excess of $\left[\alpha^{-}{ }^{32} \mathrm{P}\right] U T P$-labeled probes for $16 \mathrm{~h}$ at $56^{\circ} \mathrm{C}$. Singlestranded RNA was digested with RNase A/T1 (Pharmingen, San Diego, CA). RNase was inactivated, and the protected RNA was precipitated using RNAse inactivation buffer (Ambion, Austin, TX). L32 (ribosomal protein mRNA) was used as an internal control for loading (23). The protected fragments were resolved on $6 \%$ polyacrylamide $8 \mathrm{M}$ urea gels, visualized by autoradiography, and quantified on a Phospho Imager using ImageQuant version 1.2 software (Molecular Dynamics, Sunnyvale, CA).

In situ hybridization. In situ localization of mRNA was performed with digoxigenin-labeled antisense sheep riboprobes for IL-1 $\beta$, IL-6, MCP-1, Egr-1, and HSP70 (Roche, IN). Briefly, digoxigenin-labeled riboprobes (sense and antisense) were synthesized from cDNA templates using DIG RNA labeling kits (Roche) and diluted in hybridization buffer to a final concentration of $1 \mu \mathrm{g} / \mathrm{mL}$. The sections were pretreated with $4 \%$ paraformaldehyde, proteinase $\mathrm{K}$ treated, and hybridized with the probe overnight at 49 to $62^{\circ} \mathrm{C}$, based on GC content of probe. Sections were washed with formamide, RNase A $(100 \mu \mathrm{g} / \mathrm{mL})$ treated, and then blocked with $10 \%$ horse serum. After incubation overnight at $4^{\circ} \mathrm{C}$ with anti-digoxigenin antibody (Roche), the slides were developed with NBT-BCIP (Roche) in dark cases. The slides were monitored for color development and then stopped with TE buffer. Controls for specificity of ribo-probe binding included use of the homologous (sense) probe.

Statistics. All values are expressed as mean $\pm \mathrm{SD}$, and comparisons between intervention groups were made with two-tailed Mann-Whitney nonparametric tests or Welch $t$ tests. Significance was accepted at $p<0.05$. Figures show individual values and means, and were $\log$ transformed when appropriate.

\section{RESULTS}

The lambs had similar birth weights and had achieved similar tidal volumes and lung compliance values at the end of the 15-min resuscitation period. In the newborn ventilation group, the mean $\mathrm{FiO}_{2}$ was $0.41 \pm 0.16$ and $\mathrm{PaO}_{2}$ was $33.9 \pm$ $10.8 \mathrm{~mm} \mathrm{Hg}$. The total injury scoring was similar between ventilated groups with both fetal $(2.8 \pm 1.0)$ and newborn (3.2 \pm 0.8$)$ groups increased over controls $(0.1 \pm 0.2)$. There were bronchial epithelial disruptions in medium-sized airways without signs of hemorrhage for both ventilated groups. Lambs in the newborn group had increased alveolar wall thickness compared with the fetal group. Inflammatory cells were occasionally seen within the airways of the ventilated groups, but not in the controls.

Early growth response protein 1. Egr-1 mRNA was increased 3.5 \pm 2.1 -fold in the fetal group and increased $15.8 \pm$ 3.8-fold with stretch injury and continued ventilation in the newborn group. After 3 hours, the mRNA was expressed in the inflammatory cells in the fetal ventilation group and throughout the small airways and inflammatory cells in the newborn group (Fig. $1 A-C$ ). Egr-1 protein was localized in the fetal group to areas surrounding the small airways compared with the unventilated controls (Fig. 1E). More extensive staining of the smooth muscle and distal airspaces was seen in animals ventilated for 3 hours (Fig. $1 F$ ).

Heat shock protein 70 . HSP70 mRNA was localized to the bronchial epithelial cells in the nonventilated controls (Fig. $2 A)$. HSP70 mRNA expression was lower than controls in airway epithelial cells of the fetal group and was virtually absent from the bronchial epithelial cells and glands in the newborn group (Fig. $2 B$ and $C$ ). HSP70 mRNA decreased in 


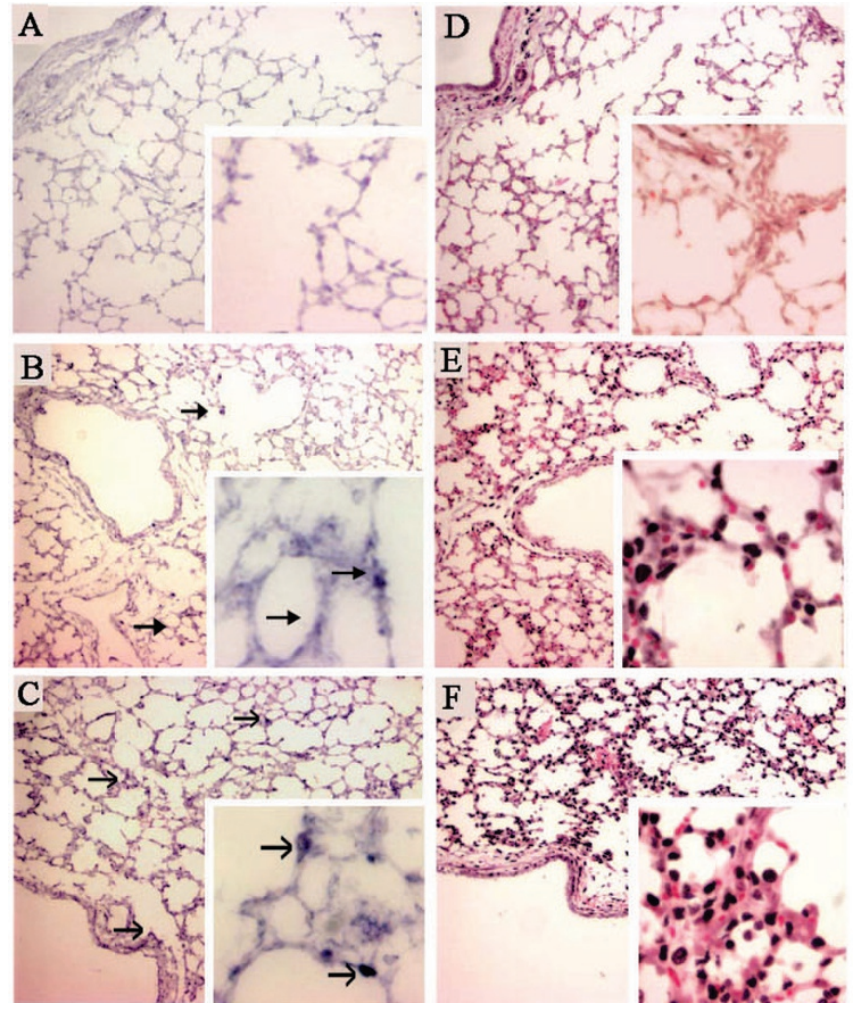

Figure 1. Egr-1 mRNA and protein induced in small airways. $A-C$, Digoxigenin-labeled in situ hybridization of Egr-1 demonstrated induction of mRNA around small airways [arrows, insert $(40 \times)$ ] with fetal ventilation $(B)$ and with newborn ventilation $(C)$. Egr-1 protein $(D-E)$ is increased in small airways of the fetal group [E, insert $(40 \times)]$ and throughout the lung parenchyma of the newborn group $(F)$ compared with controls $(D)$.
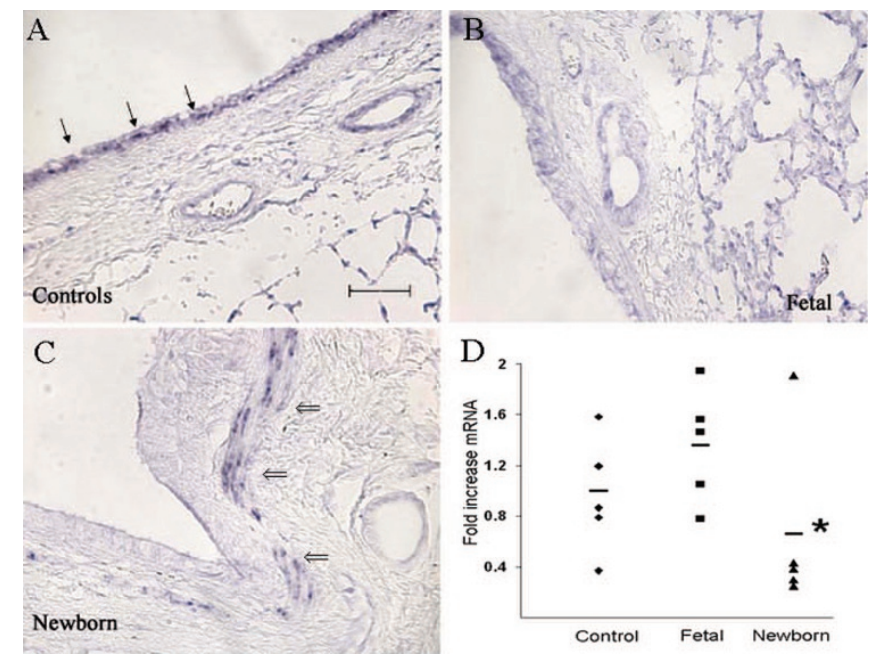

Figure 2. HSP70 mRNA. (A) HSP70 mRNA was localized to the bronchial epithelium (arrows) of nonventilated controls. B, Fetal ventilation decreased HSP70 mRNA in airway epithelial cells. $C$, Newborn ventilation induced HSP70 mRNA in the smooth muscle (open arrows) surrounding large airways. $D$, RNase protection assay for HSP70 mRNA in the lung. ${ }^{*} p<0.05 v s$ controls. Scale bar $=25 \mu \mathrm{m}$.

lung homogenates from the newborn lambs (Fig. 2D). In contrast, HSP70 mRNA appeared in the smooth muscle of the large airways after ventilation (Fig. 2C). HSP70 protein was expressed in the ciliated cells of the bronchial epithelium in the nonventilated controls (Fig. 3A); consistent with the

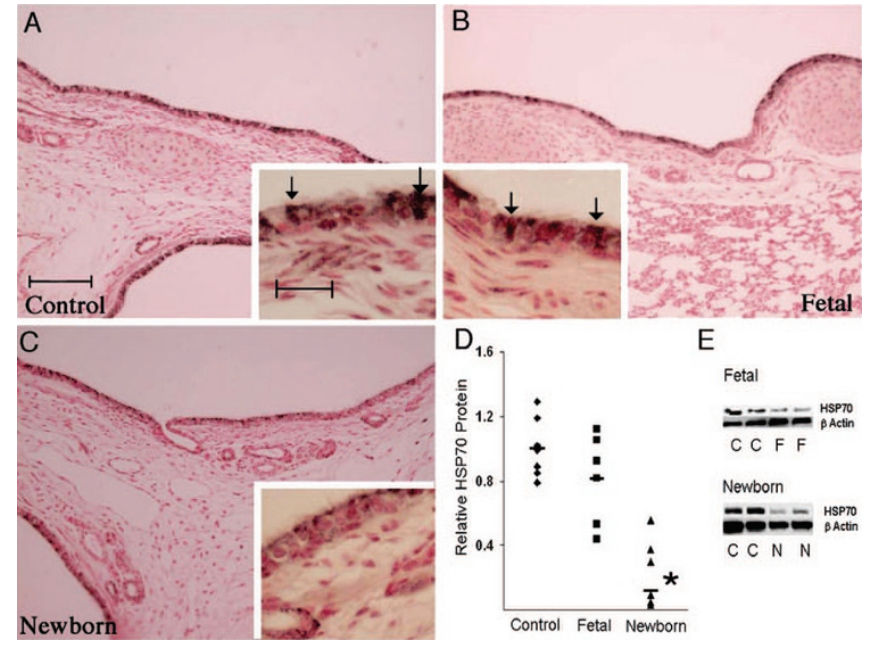

Figure 3. HSP70 immunohistochemistry. HSP70 protein was located in the ciliated cells (upper insert arrows) of the bronchial epithelium of the large airways in control lambs $(A)$. HSP70 staining was decreased with fetal $(B)$ and newborn $(C)$ ventilation. $D$, Western blot with lung homogenates demonstrated decreased protein levels in fetal $(F)$ and newborn $(N)$ lambs. $(E)$ Representative western blots. ${ }^{*} p<0.01 v s$ controls.

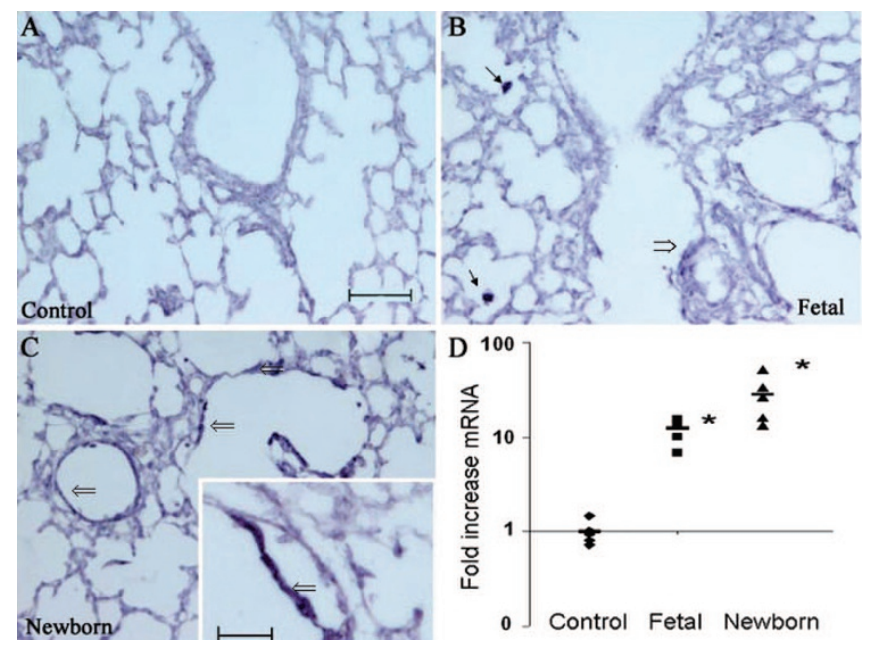

Figure 4. IL-1 $\beta$ mRNA localization with ventilation. Compared with controls $(A)$, fetal ventilation increased IL- $1 \beta$ mRNA in $(B)$ the inflammatory cells (arrows) and epithelial cells (open arrows). $C$, Induction of IL-1 $\beta$ mRNA was more evident in the epithelial cells along small airways with continued ventilation, especially in sloughed epithelium (insert). $D$, RNase protection assay for the lung tissue demonstrated increased IL- $1 \beta$ with fetal ventilation with further increase with ventilation. ${ }^{*} p<0.05 v s$ controls. Scale bar $=25 \mu \mathrm{m}$ (insert $10 \mu \mathrm{m})$.

mRNA data, the protein levels were lower in fetal and newborn lambs (Fig. $3 B$ and $C$ ). Unlike the mRNA, HSP70 protein was not increased in airway smooth muscle at $3 \mathrm{~h}$. HSP70 protein in lung homogenates was $20 \%$ lower in the fetal group and $80 \%$ lower in the newborn group (Fig. 3D). HSP70 in BAL fluid was $4 \pm 0.8$-fold higher in the fetal group and $5 \pm$ 1.3-fold higher in newborn group than in the unventilated controls. HSP70 was detected in the plasma of the unventilated controls, and levels did not change with ventilation.

IL-1 $\beta, M C P-1$ and IL-6 expression. IL- $1 \beta$ mRNA was 12 -fold higher in the fetal group and 28 -fold higher in the newborn lambs (Fig. $4 D$ ) than for controls. IL- $1 \beta$ mRNA was 


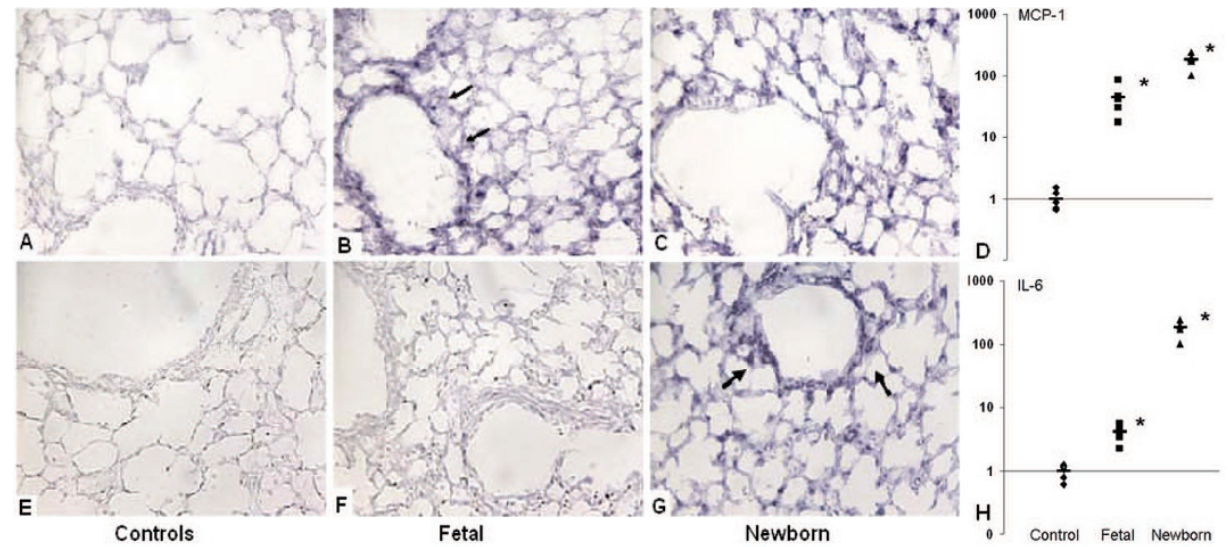

Figure 5. MCP-1 and IL-6 mRNA localization. Compared with controls $(A), \mathrm{MCP}-1$ mRNA was increased in mesenchyme surrounding small airway (arrows) with fetal ventilation $(B)$ and more diffusely with continued newborn ventilation $(C)$. IL-6 mRNA increased slightly in fetal group $(F)$, relative to controls $(E)$, and with newborn ventilation $(G)$ leading to increased mRNA in mesenchyme surrounding the small airways (arrows). RNase protection assays $(D, H)$ correlated with the expression data with MCP-1 increasing more dramatically with fetal ventilation. $* p<0.05$ vs controls.

localized to inflammatory cells (Fig. $4 B$ ) and to the bronchial epithelium of small airways, particularly in areas with bronchial epithelial sloughing (Fig. 4C). Control lungs (Fig. 4A) had no IL- $1 \beta$ mRNA. IL- $1 \beta$ protein was localized to inflammatory cells lining the small airways (data not shown).

MCP-1 was 44-fold higher relative to the control lung in the lungs of lambs in the fetal group and was increased 180-fold in the newborn group (Fig. 5). The MCP-1 was localized primarily to the parenchyma surrounding the small airways in the fetal group. MCP-1 localization was more diffuse with the 3-h newborn ventilation, involving more mesenchyme surrounding the distal airways.

In comparison with MCP-1, IL-6 mRNA increased only 4-fold in the fetal group but increased 300-fold with continued ventilation in the newborn group. In situ localization demonstrated increased mRNA in the mesenchyme surrounding the smaller airways with ventilation (Fig. 5), similar to MCP-1. Minimal expression of IL-6 mRNA was evident for the fetal group.

VEGF, VEGFR2, iNOS expression. Immunohistochemistry for iNOS (iNOS/NOSII) was negative for the fetal and newborn lambs (data not shown), suggesting that the inflammatory cells were not activated by the 3 -h interventions. VEGF mRNA in the lungs was not different from control in fetal or newborn lambs. VEGFR2 protein levels were also not different.

\section{DISCUSSION}

The initiation of ventilation with large tidal volumes caused changes in both the large and small airways of these preterm lambs. Because newborns must clear the airways of fluid before initiation of gas exchange, the fetal lung fluid is forced into the distal airspaces and lung parenchyma by the initial breaths (24). As functional residual capacity is recruited and the lung parenchyma expands, the airways are stretched by ventilation, and this airway deformation will move from the large airways to the smaller airways (25). Although epithelial sloughing was noted in medium-sized airways, extensive tissue damage and hemorrhage were not seen in these lambs. A graduated injury response occurred in the animals maintained on placental support (fetal) relative to animals exposed to continued ventilation (newborn). This study used a unique model to evaluate the stretch injury induced by initiation of ventilation at birth. Unlike adult animals, where alveolar macrophages play a primary role in the initiation of the inflammatory response to stretch injury (26), fetal sheep do not have mature macrophages in the lungs (18). Negative iNOS staining and the absence of significant numbers of inflammatory cells within areas of intense IL-6 and MCP-1 mRNA production suggest that the cells within the mesenchyme surrounding the airways initially produce these proinflammatory mediators. Therefore, this study is informative about the tissue components responsible for injury responses induced by ventilation of the preterm lung.

The cytokines had variable patterns of expression around the small airways. The IL- $1 \beta$ localization to the bronchial epithelium, including areas with extensive sloughing, is similar to the IL- $1 \beta$ injury response in the adult rats (15). Similar epithelial sloughing is seen in models of rapid expansion of a fluid-filled, surfactant-deficient small airways (27). The MCP-1 and IL-6 mRNA were localized to the small airways, but were also found in the surrounding mesenchyme. Although the location of the mRNA induction for IL-6 and MCP-1 was similar, the timing or threshold after injury seems to be different, with MCP-1 increased by 15 -min ventilation and IL-6 requiring continued ventilation for high induction. Our results demonstrate that cytokine production from stretch injury in the fetal sheep is primarily produced by the cells of the lung parenchyma.

The large airways demonstrated loss of HSP70 protein from epithelial cells without further induction of mRNA and with soluble HSP70 in the airspace after ventilation. HSP70 is an intracellular chaperone protein that is present in the epithelial cells of the lung (17). Intracellular HSP70 can help stabilize $\mathrm{I} \kappa \mathrm{B}$, can decrease NF- $\kappa \mathrm{B}$ translocation into the nucleus, and can inhibit the production of proinflammatory cytokines (28). HSP70 also can be released as extracellular HSP70 (eHSP70) (29), which can act as an endogenous ligand for Toll-like receptor 4 (TLR4) (30). In these preterm lambs, HSP70 staining was intense in the ciliated cells of the bronchial epithelium of control animals, and this epithelial HSP70 decreased with ventilation. Consistent with the expression data, HSP70 mRNA and protein expression decreased in the lung homogenates. In contrast, HSP70 protein increased in the BALF, suggesting release of HSP70 from the injured epithelium into the airway. Interestingly, HSP70 levels did not 
increase in the plasma. The release of HSP70 into the BAL probably resulted from active exocytosis in the form of eHSP70, because the intact epithelium lacked HSP70. We previously showed increased TLR4 mRNA expression in these lungs, which could result from eHSP70 signaling (14). Unlike adult animals, such as the rat (15), there was no increased HSP70 mRNA with ventilation-induced injury. Ventilation of preterm sheep decreased the HSP70 mRNA and protein in the bronchial epithelial cells. This difference in responses was reported for newborn and adult rats (31), suggesting that the difference may result from the stage of lung development.

The smooth muscle surrounding the larger airways responded to the $15 \mathrm{~min}$ of mechanical ventilation, as demonstrated by increased HSP70 mRNA. This localization of HSP70 expression to the smooth muscle following airway stretch is a novel observation, and it is consistent with the increase in HSP70 in the skeletal muscles of mice exposed to excessive cyclical stretch (32). The increase in HSP70 mRNA seen in this study may indicate that damage is caused by distending the airways. The airway effects may be magnified by the more compliant airways of preterm animals, which also have decreased contractility of airway smooth muscle (33). The initial expansion of the fluid-filled lung is anatomically location dependent, with newborn rabbit lungs aerating the dependent portions of their lungs more slowly than nondependent regions (24). We only had tissue from the right upper lobe to evaluate, and other areas of the lung may have had differing degrees of injury (34). Our measurements were limited to 3 hours, and changes in the smooth muscle and HSP70 may become more prominent with time. Continuous stretching of the compliant airways of premature infants with ventilation could lead to the smooth muscle hypertrophy or airway malacia, and both abnormalities have been reported for premature infants (35).

Early growth protein 1 (Egr-1) increased with both fetal and newborn ventilation and may be an early initiator of the stretch-induced lung inflammation. Fetal ventilation increased the intensity of staining in the nuclei of cells surrounding the small airways. In situ localization for Egr-1 mRNA was similar to protein localization, suggesting the $15 \mathrm{~min}$ of fetal ventilation primarily injured the airways. Similar to our findings, increased expression Egr-1 was reported in rats and lambs exposed to high tidal volume ventilation within $30 \mathrm{~min}$ $(15,16)$. After 3 hours of ventilation, the majority of the cells in the preterm lungs were Egr-1 positive. In mice, Egr-1 signaling has been linked to ventilator-induced lung injury (VILI), as Egr-1 knock out mice do not develop VILI, and inhibitors of Egr-1, such as peroxisome proliferator-activated receptor- $\gamma$ agonists, decrease VILI (36). Egr-1 knock out mice also have decreased levels of circulating inflammatory mediators and survive longer after pulmonary ischemia-reperfusion (37). We demonstrate that an early response gene (Egr-1) is induced by $15 \mathrm{~min}$ of ventilation, predominantly in cells surrounding the small airways of the preterm lung.

Our studies provide clues to pathogenesis of lung abnormalities in preterm infants. Although alveolar simplification is the hallmark of BPD on autopsy in the postsurfactant era, residual small airway injury is characteristic of older children with a history of BPD. School-aged children diagnosed with moderate-to-severe BPD demonstrated decreased $\mathrm{FEV}_{1}$ (5). Children born extremely prematurely also demonstrated decreased exercise performance (9). Alveolar simplification leads to the need for oxygen in infants with BPD, and airway injury and possible airway smooth muscle hypertrophy may contribute to the decreased $\mathrm{FEV}_{1}$ seen in infants with BPD. The initiation of ventilation induced expression of a stressresponse and inflammatory cytokines primarily in small- and medium-sized airways and may be a first step toward persistent airway abnormalities.

\section{REFERENCES}

1. Fanaroff AA, Stoll BJ, Wright LL, Carlo WA, Ehrenkranz RA, Stark AR, Bauer CR, Donovan EF, Korones SB, Laptook AR, Lemons JA, Oh W, Papile LA, Shankaran S, Stevenson DK, Tyson JE, Poole WK; NICHD Neonatal Research Network 2007 Trends in neonatal morbidity and mortality for very low birthweight infants. Am J Obstet Gynecol 196:147.e1-148.e1

2. van Marter LJ, Pagano M, Allred EN, Levitorn A, Kuban KC 1992 Rate of bronchopulmonary dysplasia as a function of neonatal intensive care practices. J Pediatr 120:938-946

3. Morley CJ, Davis PG, Doyle LW, Brion LP, Hascoet JM, Carlin JB 2008 Nasal CPAP or intubation at birth for very preterm infants. N Engl J Med 358:700-708

4. Ammari A, Suri MS, Milisavljevic V, Sahni R, Bateman DA, Sanocka U, Ruzal-Shapiro C, Wung JT, Polin RA 2005 Variables associated with the early failure of nasal CPAP in very low birth weight infants. J Pediatr 147:341-347

5. Hennessy EM, Bracewell MA, Wood N, Wolke D, Costeloe K, Gibson A, Marlow N 2008 Respiratory health in pre-school and school age children following extremely preterm birth. Arch Dis Child 93:1037-1043

6. Coalson JJ 2003 Pathology of new bronchopulmonary dysplasia. Semin Neonatol $8: 73-81$

7. Vrijlandt EJ, Gerritsen J, Boezen HM, Grevink RG, Duiverman EJ 2006 Lung function and exercise capacity in young adults born prematurely. Am J Respir Crit Care Med 173:890-896

8. Moss TJ 2006 Respiratory consequences of preterm birth. Clin Exp Pharmacol Physiol 33:280-284

9. Smith LJ, van Asperen PP, McKay KO, Selvadurai H, Fitzgerald DA 2008 Reduced exercise capacity in children born very preterm. Pediatrics 122:e287-e293

10. Robertson D 1984 Pathology and pathophysiology of neonatal surfactant deficiency. In: Robertson B, Van Golde LMG, Batenburg JJ (eds) Pulmonary Surfactant. Elseiver Science Publishers, Amsterdam, pp 383-418

11. Shaffer TH, Bhutani VK, Wolfson MR, Penn RB, Tran NN 1989 In vivo mechanical properties of the developing airway. Pediatr Res 25:143-146

12. Jobe AH, Hillman N, Polglase G, Kramer BW, Kallapur S, Pillow J 2008 Injury and inflammation from resuscitation of the preterm infant. Neonatology 94:190-196

13. Polglase GR, Hillman NH, Pillow JJ, Cheah FC, Nitsos I, Moss TJ, Kramer BW, Ikegami M, Kallapur SG, Jobe AH 2008 Positive end-expiratory pressure and tidal volume during initial ventilation of preterm lambs. Pediatr Res 64:517-522

14. Hillman NH, Moss TJ, Kallapur SG, Bachurski C, Pillow JJ, Polglase GR, Nitsos I, Kramer BW, Jobe AH 2007 Brief, large tidal volume ventilation initiates lung injury and a systemic response in fetal sheep. Am J Respir Crit Care Med 176:575-581

15. Copland IB, Kavanagh BP, Engelberts D, McKerlie C, Belik J, Post M 2003 Early changes in lung gene expression due to high tidal volume. Am J Respir Crit Care Med 168:1051-1059

16. Wallace MJ, Probyn ME, Zahra VA, Crossley K, Cole TJ, Davis PG, Morley CJ, Hooper SB 2009 Early biomarkers and potential mediators of ventilation-induced lung injury in very preterm lambs. Respir Res 10:19

17. Wheeler DS, Wong HR 2007 Heat shock response and acute lung injury. Free Radic Biol Med 42:1-14

18. Kramer BW, Jobe AH, Ikegami M 2003 Monocyte function in preterm, term, and adult sheep. Pediatr Res 54:52-57

19. Mulrooney N, Champion Z, Moss TJ, Nitsos I, Ikegami M, Jobe AH 2005 Surfactant and physiological responses of preterm lambs to continuous positive airway pressure. Am J Respir Crit Care Med 171:488-493

20. Kallapur SG, Jobe AH, Ball MK, Nitsos I, Moss TJ, Hillman NH, Newnham JP, Kramer BW 2007 Pulmonary and systemic endotoxin tolerance in preterm fetal sheep exposed to chorioamnionitis. J Immunol 179:8491-8499

21. Kramer BW, Moss TJ, Willet K, Newnham J, Sly P, Kallapur SG, Ikegami M, Jobe A 2001 Dose and time response after intra-amniotic endotoxin in preterm lambs. Am J Respir Crit Care Med 164:982-988

22. Chomczynski P, Mackey K 1995 Modification of the TRI reagent(TM) procedure for isolation of RNA from polysaccharide- and proteoglycan-rich sources. Biotechniques 19:942-945

23. Kallapur SG, Willet KE, Jobe AH, Ikegami M, Bachurski C 2001 Intra-amniotic endotoxin: chorioamnionitis precedes lung maturation in preterm lambs. Am J Physiol Lung Cell Mol Physiol 280:L527-L536 
24. Hooper SB, Kitchen MJ, Wallace MJ, Yagi N, Uesugi K, Morgan MJ, Hall C, Siu KK, Williams IM, Siew M, Irvine SC, Pavlov K, Lewis RA 2007 Imaging lung aeration and lung liquid clearance at birth. FASEB J 21:3329-3337

25. Siew ML, Te Pas AB, Wallace MJ, Kitchen MJ, Lewis RA, Fouras A, Morley CJ, Davis PG, Yagi N, Uesugi K, Hooper SB 2009 Positive end-expiratory pressure enhances development of a functional residual capacity in preterm rabbits ventilated from birth. J Appl Physiol 106:1487-1493

26. Eyal FG, Hamm CR, Parker JC 2007 Reduction in alveolar macrophages attenuates acute ventilator induced lung injury in rats. Intensive Care Med 33:1212-1218

27. Huh D, Fujioka H, Tung YC, Futai N, Paine R III, Grotberg JB, Takayama S 2007 Acoustically detectable cellular-level lung injury induced by fluid mechanical stresses in microfluidic airway systems. Proc Natl Acad Sci USA 104:18886-18891

28. Wong HR, Wispe JR 1997 The stress response and the lung. Am J Physiol 273:L1-L9

29. Calderwood SK, Mambula SS, Gray PJ Jr, Theriault JR 2007 Extracellular heat shock proteins in cell signaling. FEBS Lett 581:3689-3694

30. Chase MA, Wheeler DS, Lierl KM, Hughes VS, Wong HR, Page K 2007 Hsp72 induces inflammation and regulates cytokine production in airway epithelium through a TLR4- and NF-kappaB-dependent mechanism. J Immunol 179:63186324
31. Copland IB, Martinez F, Kavanagh BP, Engelberts D, McKerlie C, Belik J, Post M 2004 High tidal volume ventilation causes different inflammatory responses in newborn versus adult lung. Am J Respir Crit Care Med 169:739-748

32. Stary CM, Walsh BJ, Knapp AE, Brafman D, Hogan MC 2008 Elevation in heat shock protein 72 mRNA following contractions in isolated single skeletal muscle fibers. Am J Physiol Regul Integr Comp Physiol 295:R642-R648

33. Cullen AB, Cooke PH, Driska SP, Wolfson MR, Shaffer TH 2006 The impact of mechanical ventilation on immature airway smooth muscle: functional, structural, histological, and molecular correlates. Biol Neonate 90:17-27

34. Otto CM, Markstaller K, Kajikawa O, Karmrodt J, Syring RS, Pfeiffer B, Good VP, Frevert CW, Baumgardner JE 2008 Spatial and temporal heterogeneity of ventilatorassociated lung injury after surfactant depletion. J Appl Physiol 104:1485-1494

35. Tiddens HA, Hofhuis W, Casotti V, Hop WC, Hulsmann AR, de Jongste JC 2008 Airway dimensions in bronchopulmonary dysplasia: implications for airflow obstruction. Pediatr Pulmonol 43:1206-1213

36. Hoetzel A, Dolinay T, Vallbracht S, Zhang Y, Kim HP, Ifedigbo E, Alber S, Kaynar AM, Schmidt R, Ryter SW, Choi AM 2008 Carbon monoxide protects against ventilator-induced lung injury via PPAR-gamma and inhibition of Egr-1. Am J Respir Crit Care Med 177:1223-1232

37. Yan SF, Fujita T, Lu J, Okada K, Shan Zou Y, Mackman N, Pinsky DJ, Stern DM 2000 Egr-1, a master switch coordinating upregulation of divergent gene families underlying ischemic stress. Nat Med 6:1355-1361 